\title{
Critical analysis of the European Union directive which regulates the use of biofuels: An approach to the Spanish case
}

\author{
Fernando Hernández Sobrino*, Carlos Rodríguez Monroy \\ Department of Business Administration, School of Industrial Engineering, Universidad Politécnica de Madrid, José Gutierrez Abascal, 2, 28006 Madrid, Spain
}

A R T ICLE I N F O

\section{Keywords:}

Ethanol

Bioethanol

Biofuel

Citric waste

EU directive 2003/30/EC

\begin{abstract}
A B S T R A C T
For more than a decade we have lived in a period where the so-called "sustainability" is crucial and is motivated primarily by the social awareness of achieving a balance between human development and the conservation of the environment. This philosophy has a direct and inevitable impact on business and politics. Governments have long since been developing standards and encouraging various diverse initiatives whose aim is to defend the environment.

In recent times, the global debate on the environment has been centred on $\mathrm{CO}_{2}$ emissions. This gas is the major cause of the "greenhouse effect" and people are more concerned with the idea that the emissions of this gas should be minimized. As a result of this concern, the Kyoto Protocol was enacted and subscribed to by many countries, setting the maximum gas emissions for them.

Fossil fuels are a major source of $\mathrm{CO}_{2}$ emissions. In 2003 the European Union (EU) directive 2003/30/ EC [2003/30/EC Directive of the European Parliament and the Council-8th may 2003. On the promotion of the use of biofuels or other renewable fuels for transport] was developed with the aim of promoting the use of biofuels as a substitute for diesel or petrol among European Union countries as well as to contribute to fulfilling the commitments on climate change, security of supply in environmentally friendly conditions and the promotion of renewable energy sources.

In order to achieve these goals, the directive forces all EU members to ensure that at least $5.75 \%$ of all petrol and diesel fuels sold for transport purposes are biofuels before December 31 of 2010. European Union countries have social and economic characteristics unique to themselves. The energy dependence from foreign sources, the features of the agricultural sector or the degree of industrialization varies greatly from one country to another. In this context, it is questionable whether the obligation imposed by this directive applies to achieve uniform and/or identical goals in each of the countries involved and whether the actions of the various governments are also aligned with these goals.
\end{abstract}

\section{Contents}

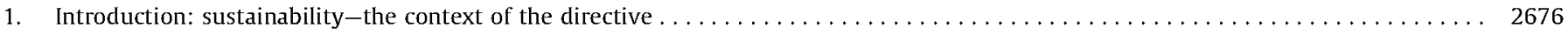

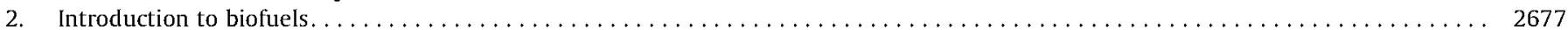

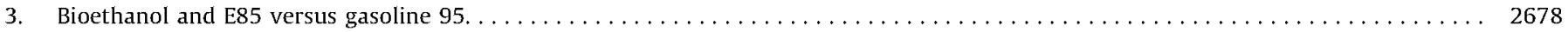

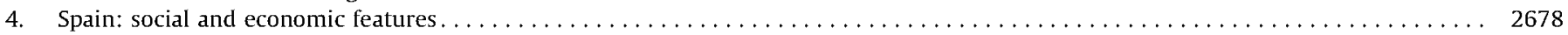

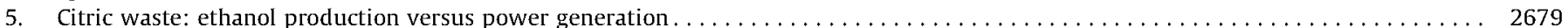

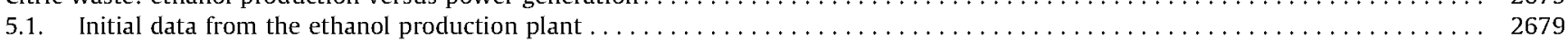

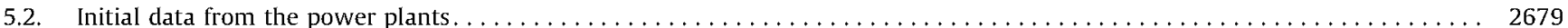

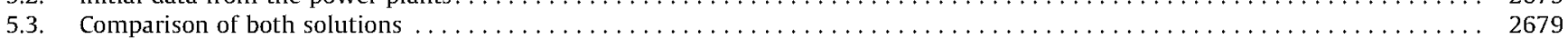

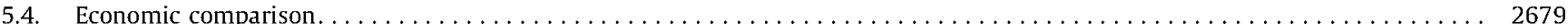

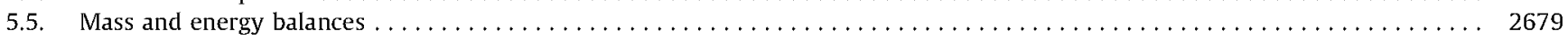

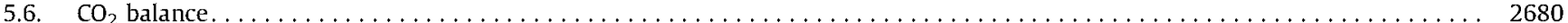

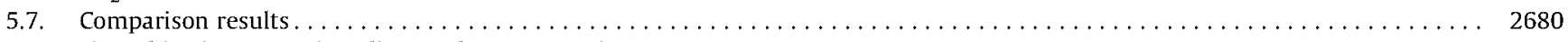

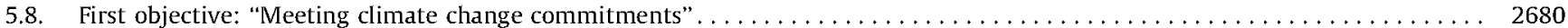

5.9. Second objective: "Environmentally friendly security of supply" $\ldots \ldots \ldots \ldots \ldots \ldots$

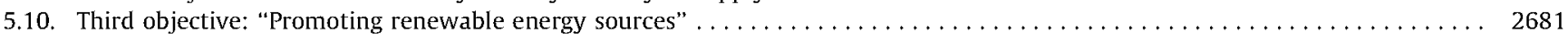

* Corresponding author. Tel:: +34915748992.

E-mail addresses: sobrinof@gmail.com (F.H. Sobrino), crmonroy@etsii.upm.es (C.R. Monroy). 


\section{Introduction: sustainability-the context of the directive}

At present we live in an age where the so-called "sustainability" is more appreciated than other trends such as quality, speed and production flexibility which ruled the last quarter-century. Fig. 1 shows a summary of these trends.

This sustainability era is motivated primarily by social awareness in achieving a balance between human development and the conservation of the environment. "Sustainability" and in turn "sustainable development" are terms that mean different things to different people, making it impossible to provide a single definition. The original definition (and the one still most widely used) of sustainable development was made in the Bruntland Report (Our Common Future, World Commission on Environment and Development in 1987) which defined it as:

"Development that meets the needs of the present generation without compromising the ability of future generations to meet their own needs".

Sustainable development is all about ensuring a better quality of life for everyone [2], now and for generations to come. This can be achieved through the three strands of social equity which recognises the social needs of everyone, the maintenance of stable levels of economic growth and employment, and the prudent use of natural resources, whilst protecting the environment. This can be shown diagrammatically in Fig. 2 .

An even balance between the circles is needed for sustainability [3]. For example, outstanding economic performance at the cost of the community is not sustainable [4]. Neither is protecting the environment beyond reasonable means and consequently stunting any economic activities. Sustainability does not demand the 'perfect' solution. Sustainable development is essentially a goal or vision that forward looking organisations are working towards [5]. A sustainable approach is a balanced approach.

This philosophy has influenced marketing strategies of companies. Many firms boast about how "green" or "bio" their products and services are. Furthermore, companies know that being (or saying that they are) "bio" or "green" can represent an added value to potential clients, so it can be more profitable. The companies maintain that their activities do not damage the environment or that their products, once used, do not pollute or that at the end of their product life they can be easily recycled.

Here are some examples:

- Chemicals: Certain companies (manufacturers of detergents or cleaning products) state that when products are disposed through the sewer system, they do not pollute the environment

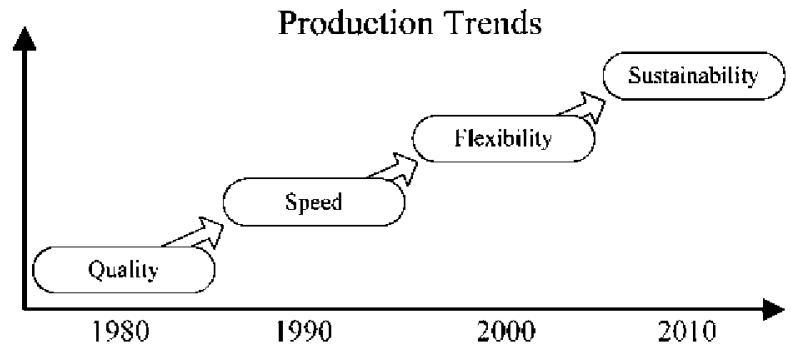

Fig. 1. Productions trends in recent years. Source: A. de la Torre - ICADE Universidad Pontificia Comillas - Madrid.
- Power plants: Many companies project the idea that they produce electricity through non-polluting or low environmental impact methods (hydro, wind, solar, etc.).

- Automotive industry: Some manufacturers claim that a high percentage of the components used in their models can be recycled.

But this idea of sustainability is not found only in the business field. Governments and politicians also know that being "green", "ecologically friendly" or simply "eco" is a very political savvy method and a tactic to amass popular votes and, therefore, they invariably use it. Indeed, it has been a few years since governments have been diligently developing standards and encouraging initiatives aiming at defending the environment. Amongst these initiatives we find the selection and separation of solid waste for further treatment, the recycling of buildings or the recycling of vehicles.

In recent times, the global debate on the environment has focused primarily on $\mathrm{CO}_{2}$ emissions. This gas is a major cause of the so-called "greenhouse effect" and there is an increased awareness of the idea that it should be minimized. As a result of this awareness the Kyoto Protocol was issued to set the maximum $\mathrm{CO}_{2}$ emissions for all the countries that have subscribed to it.

Without doubt, one of the major sources of $\mathrm{CO}_{2}$ emissions is the use of fossil fuels (primarily coal, petroleum and natural gas) [6]. It must be taken into account that all fuels containing carbon generate carbon dioxide during their combustion and, all fuels, both of vegetable and mineral origin, have this element in their chemical composition.

In 2003 the European Union directive 2003/30/EC [1] was enacted with the sole aim of promoting the use of biofuels as a substitute for diesel or gasoline and to reach the following objectives:

- The fulfilment of the commitments to climate change. That is, reducing the emissions of carbon dioxide and thus complying with the Kyoto Protocol.

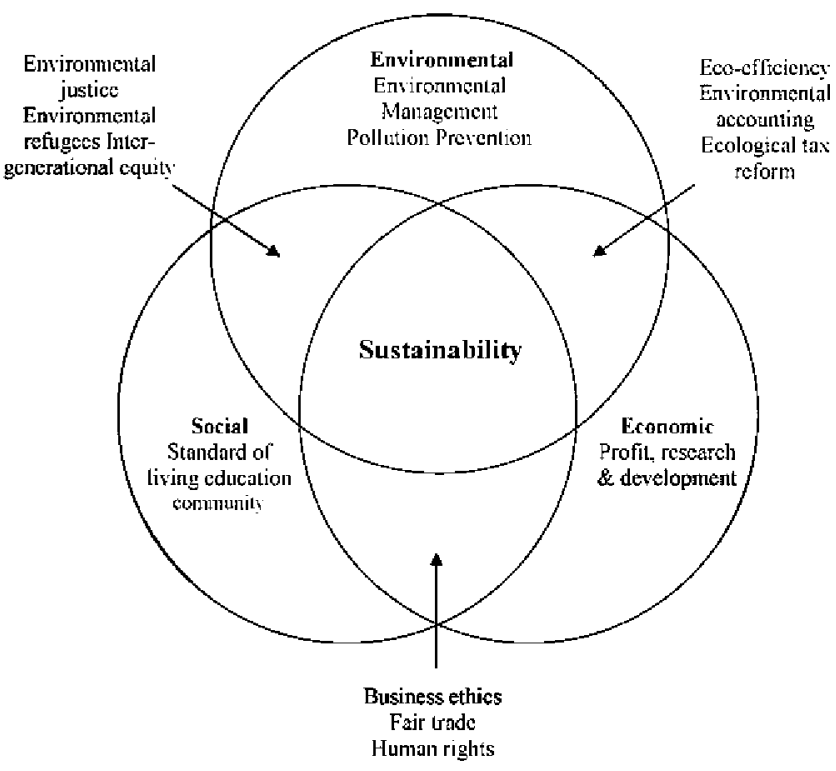

Fig. 2. Issues within the three spheres of sustainability. Source: University of Michigan [2]-sustainability assessment. 


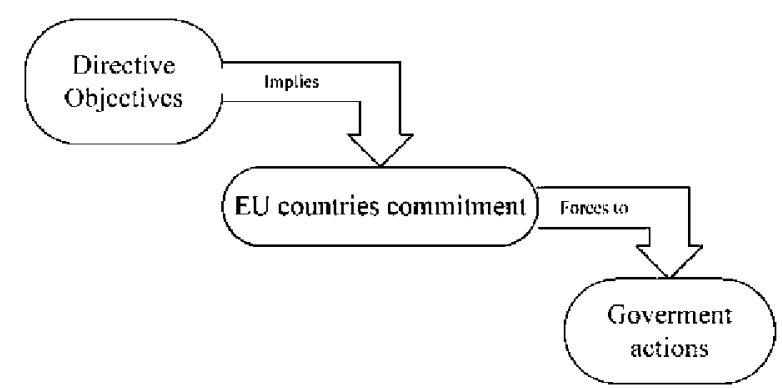

Fig. 3. Government actions alignment with the directive. Source: European Union directive 2003/30/EC [1] and authors.

- The security of supply under environmentally friendly conditions, that is, finding energy sources to avoid absolute dependence from foreign sources.

- The promotion of renewable energy sources, i.e., to find alternative energy sources that are less harmful to the environment.

In order to achieve these goals, the directive requires all EU countries to consume a minimum of $5.75 \%$ of biofuels in all petrol and diesel fuel sold for transport purposes before 31 December 2010.

Are the objectives of the directive consistent with the obligations imposed on the EU countries? Or in other words: Is the obligation in alignment with the objectives pursued?

Being a compulsory directive for all EU members, individual EU governments are encouraging actions to comply with it. It is however important to note that the actions of governments are perhaps aimed at fulfilling the obligations fixed by the directive but not at fulfilling its own unique objectives (Fig. 3 ).

The European Union is made up of 27 countries that have specific social and economic characteristics. Energy dependence or degree of industrialization varies greatly from one country to another. In this context, it is necessary to consider:

- If the obligation imposed by the directive is inadequate for achieving the goals of the directive in each of the countries.

- If government actions are aligned with the objectives set by the directive. That is, if government actions are aligned with the objectives (Fig. 4).

The outline for this article is as follows:

1. Establish a comparison between the fossil fuel currently being used (gasoline 95) and its potential biofuel substitutes (ethanol and E85) for Otto-cycle engine vehicles.

2. Describe briefly some relevant social and economic factors for a EU country, such as Spain describing its energy dependence on

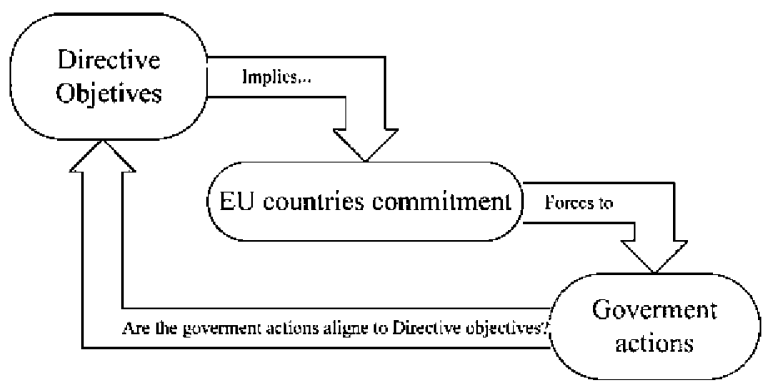

Fig. 4. Government actions and directive objectives alignment. Source: European Union directive 2003/30/EC [1] and authors. external and foreign sources and its potential to produce biofuels.

3. In acknowledging these points, two possible uses will be compared for the same raw material that is abundant in Spain: citrus waste. The potential uses of this waste are to produce electricity or to produce ethanol. The aim is to check the degree of fulfilment of the objectives set by the directive in each case.

\section{Introduction to biofuels}

Biofuel can be broadly defined as a solid, liquid, or gas fuel derived from recently dead biological material. This distinguishes it from fossil fuels, which are derived from long dead biological material. Biofuel can be theoretically produced from any (biological) carbon source, although the most common by far is photosynthetic plants. Many different plants and plant-derived materials are used for biofuel production. Biofuels are used globally, most commonly to power vehicles and cooking stoves. Biofuel industries are expanding in Europe, Asia and the Americas.

In theory, biofuels offer the possibility of producing energy without a net increase of carbon into the atmosphere because the plants used to produce the fuel may have removed $\mathrm{CO}_{2}$ from the atmosphere, unlike fossil fuels which return carbon which was stored beneath the Earth's surface for millions of years into the air. Hence, biofuel might be nearly carbon neutral and less likely to increase atmospheric concentrations of greenhouse gases (though doubts have been raised as to whether this benefit can be achieved in practice as indicated below). The use of biofuels might also reduce the already heavy dependence on petroleum and enhance energy security.

There are two common strategies for producing biofuels. One is to grow crops high in either sugar (sugar cane, sugar beet, and sweet sorghum) or starch (corn and maize), and then use yeast fermentation to produce ethyl alcohol (ethanol). The second is to grow plants that contain high amounts of vegetable oil, such as oil palm or soybean. When these oils are heated, their viscosity is reduced, and they can be burned directly in a diesel engine, or the oils can be chemically processed to produce fuels such as biodiesel. Wood can also be converted into biofuels such as wood gas, methanol or ethanol fuel. It is also possible to make cellulosic ethanol from non-edible plant parts, but this can be difficult to accomplish economically.

Biofuels are discussed as having significant roles in a variety of international issues, including: mitigation of carbon emissions levels and oil prices, the "food versus fuel" debate, deforestation and soil erosion, impact on water resources, and energy balance and efficiency.

The current situation of biofuels for transportation is as follows:

- Biodiesel: Intended to replace all or part of the diesel fuel used in diesel engines.

- Ethanol: Intended to replace wholly or partly gasoline 95 in Ottocycle engines [7]. It is also being commercialised under different mixes in the market:

- E10: $10 \%$ ethanol; $90 \%$ gasoline 95

- E85: 85\% ethanol; 15\% gasoline 95

E100: ethanol 100\%. (No gasoline 95 in its composition.)

Of all these mixtures, E85 has the highest acceptance in the market. E85 fuel stations are emerging across Europe to supply it and there are already manufacturers whose cars are being designed to use this fuel, such as Ford, Renault and Saab among others.

At this point, we attempt to make a comparison between fossil fuels and biofuels in the technical and economic aspects 
Table 1

Price and $\mathrm{CO}_{2}$ emissions comparison for gasoline 95 and E85.

\begin{tabular}{lll}
\hline & Gasoline 95 & E85 \\
\hline Petrol station prices in Spain (July 2008) & $1.231 € / 1$ & $0.85 € / 1$ \\
$\mathrm{CO}_{2}$ emissions & $2674 \mathrm{~g} / \mathrm{l}$ & $1685 \mathrm{~g} / \mathrm{l}$
\end{tabular}

Source: Authors.

\section{Bioethanol and $\mathbf{E 8 5}$ versus gasoline 95}

Let us proceed to compare the price and $\mathrm{CO}_{2}$ emissions per litre of gasoline 95 with a potential biofuel substitute: the $\mathrm{E} 85$, the most extended at the moment (Table 1).

Gasoline 95 price per litre is $30.59 \%$ higher than E85 and gasoline $95 \mathrm{CO}_{2}$ emissions are $58.7 \%$ larger than $\mathrm{CO}_{2}$ emissions from $\mathrm{E} 85$ fuel. These figures lead to confusion. This is because the logical measure unit for this is not per unit of volume but per unit of energy. Table 2 shows prices per unit of energy.

Table 2 indicates that gasoline 95 is $1.22 \%$ more expensive per unit of energy than E85. This is because, in terms of energy, a litre of E85 is equivalent to 0.6961 of gasoline 95 . In addition to this, it should be considered that, in the E85 price, ethanol is not taxed with the excise duty on hydrocarbons which is applied in Spain (which is $37.1 \%$ ). Hence, in case those tax burdens were equal for both fuels, the price difference would be more favourable for gasoline 95. Table 3 shows the application of the gasoline 95 scheme price to E85.

Under this scheme, E85 price before taxes should be $0.43 € / 1$ (gasoline 95 's is $0.56 € / 1)$. Within this price $(0.43 € / 1)$ the $15 \%$ of gasoline 95 that contains $E 85$ is included. The price of this gasoline 95 is $0.56 € / 1$. Hence, the price per litre of ethanol before taxes might be $0.40 € / 1$.

Nowadays, ethanol price per litre in the market and without value added tax (VAT) is $0.78 € / 1$. It is almost twice the price that it should have to compete with gasoline 95 .

Table 4 shows $\mathrm{CO}_{2}$ emissions per unit of energy.

Referring to $\mathrm{CO}_{2}$ emissions, it seems that gasoline 95 produces $30.23 \%$ more $\mathrm{CO}_{2}$ per unit of energy than E85. There is a controversy when it comes to evaluate the $\mathrm{CO}_{2}$ emissions and energy balance of ethanol. This is because there are authors [8] who argue that, depending on the raw material used to produce ethanol, this biofuel might require more energy to be processed than the energy that it is able to release in its combustion and $\mathrm{CO}_{2}$

\section{Table 2}

Price for gasoline 95 and E85 per unit of energy.

\begin{tabular}{ll}
\hline Gasoline 95 & E85 \\
\hline $37.21 € / G \mathrm{~J}$ & $36.76 € / G \mathrm{~J}$
\end{tabular}

Source: Authors.

Table 3

Price scheme of gasoline 95 applied to E85.

\begin{tabular}{llll}
\hline & $\%$ & Gasoline 95 & E85 \\
\hline Price & 100 & $1.11 € / 1$ & $0.85 € / 1$ \\
Price before taxes & 50.31 & $0.56 € / 1$ & $0.43 € / 1$ \\
Taxes & 49.69 & $0.55 € / 1$ & $0.42 € / 1$ \\
\hline
\end{tabular}

Source: Authors.

Table 4

$\mathrm{CO}_{2}$ emissions for gasoline 95 , ethanol and E85 per unit of energy.

\begin{tabular}{lll}
\hline Gasoline 95 & Ethanol & E85 \\
\hline $73.15 \mathrm{~g} / \mathrm{MJ}$ & $51.31 \mathrm{~g} / \mathrm{MJ}$ & $56.17 \mathrm{~g} / \mathrm{MJ}$
\end{tabular}

Source: Authors. emissions may also be higher than gasoline 95 [9]. Therefore, E85 might emit more $\mathrm{CO}_{2}$ than gasoline 95 .

\section{Spain: social and economic features}

Spain is a country that has a very strong dependence on foreign energy sources. $81 \%$ of all energy is imported compared to $53.8 \%$ which is the average percentage in the European Union. On the other hand, in relation to electricity generation, Spain is a country with a very diverse mix. The following chart shows the origin of electricity in the year 2007 [10] in Spain (Fig. 5).

Note that almost $1 \%(0.85 \%)$ of the electricity generated $(2384 \mathrm{GWh})$ comes from $100 \%$ foreign sources of raw materials (oil and methane gas). Besides, all the methane gas used in mixedcogeneration power plants and a significant amount of the coal is imported too. All these energy sources also generate $\mathrm{CO}_{2}$.

According to this, in Spain $400 \mathrm{~g}$ per kWh are generated. In France the equivalent figure is only $90 \mathrm{~g}$ per $\mathrm{kWh}$ due to the dependence of this country on nuclear fuel. For Spain this represents a major obstacle to comply with the Kyoto Protocol. This is also one of the objectives of the European Union directive.

On the other hand, these data suggest that in terms of power generation there is still room to find alternatives to achieve the objectives of the directive such as meeting climate change commitments (both raw materials emit $\mathrm{CO}_{2}$ ), environmentally friendly security of supply (both raw materials must be imported) and promoting renewable energy sources.

Besides this, Spain has a strong agricultural sector. The Comunidad Valenciana region alone produces $462,500 \mathrm{Tm}$ of citric waste per year. In order to accomplish the mandatory command of the Directive, a government initiative to process this waste and transform it into ethanol has been promoted. This plant is to be built in L'Alcudia (Valencia/Spain) [11,12].

At this point we attempt to make an economic and technical comparison of the two different applications for citric waste: the ethanol production and power generation in order to know which one is the best to achieve the goals outlined in the 2003/30/EC directive.

It is important to remark that this directive applies for transport purposes only. Hence, the production of electricity does not accomplish it, but the main goal of this research is to discover which application really achieves objectives of the directive better.

\section{Energy production in Spain (2007)} (GWh)

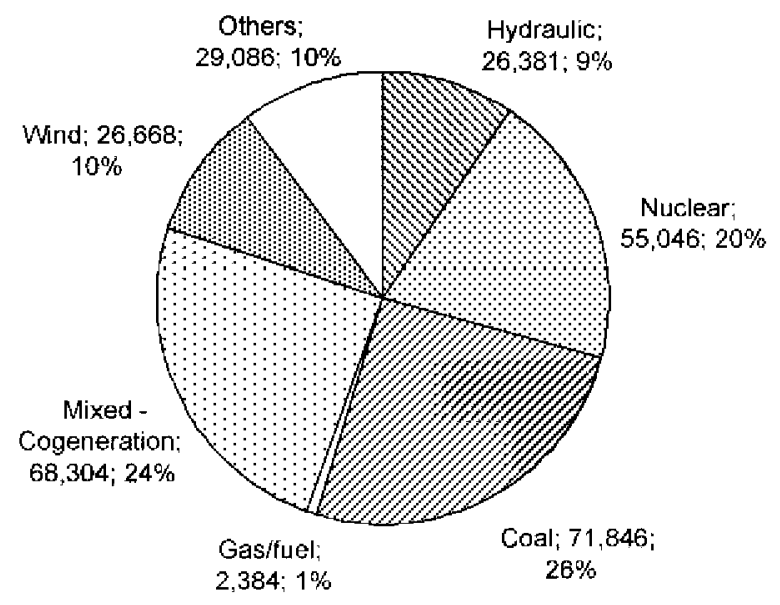

Fig. 5. Energy production in Spain (2007). Source: Red Eléctrica de España [10]. 


\section{Citric waste: ethanol production versus power generation}

A technical and economic study is to be performed to compare two different applications of citric waste: the construction and exploitation of an ethanol production plant and the construction and operation of two thermal power stations. The study was made based on the following assumptions:

- Ethanol produced at the production plant will replace an equivalent amount of gasoline $\mathbf{9 5}$ in energy terms and will be used as an automotive fuel.

- Electricity generated by thermal power plants will replace an equivalent amount of electricity produced in a gas or fuel oil power plant.

- The required energy and $\mathrm{CO}_{2}$ emissions for citric cultivations will not be taken into account, except for the energy and the $\mathrm{CO}_{2}$ emissions coming from the transportation of citric waste to the ethanol production plant and to the power plants.

\subsection{Initial data from the ethanol production plant}

Initial data for the ethanol plant are shown in Table 5.

\subsection{Initial data from the power plants}

Initial data for power plants are shown in Table 6.

\subsection{Comparison of both solutions}

Table 7 shows the technical comparison for both solutions.

\subsection{Economic comparison}

Table 8 shows the economic comparison of both solutions.

Table 5

Initial data for the ethanol plant.

\begin{tabular}{ll}
\hline Datum & Value \\
\hline Citric waste performance & 801 of ethanol per Tm of citric waste \\
Transportation average distance & $110 \mathrm{~km}$ \\
Initial investment & $40,000,000 €$ \\
WACC $^{\mathrm{b}}$ (NPV term) & $5 \%$ \\
Building time & 2 years \\
Operating time & 19 years \\
Opex & $80 \%$ incomes of ethanol sells
\end{tabular}

Source: CIEMAT and authors.

${ }^{a}$ An ethanol plant of 100 million litres per year capacity requires an initial investment of 100 million euros. It is estimated that an ethanol plant of 37 million litres per year capacity requires an initial investment of approximately 40 million euros.

b It is assumed that the weighted average cost of capital (WACC) is the same for both projects. However, the ethanol plant risk is actually higher than the power plants risk since obsolescence risk of ethanol plant is higher than obsolescence risk for power plants.

Table 6

Initial data for power plants.

\begin{tabular}{ll}
\hline Datum & Value \\
\hline Quantity & 2 \\
Nominal power (per power plant) & $50 \mathrm{MW}$ \\
Initial investment (per power plant) & $50,000,000 €$ \\
WACC (NPV term) & $5 \%$ \\
Building time & 2 years \\
Operating time & 19 years \\
Transportation average distance & $70 \mathrm{~km}$ \\
\hline
\end{tabular}

Source: Serled Consultores and authors.
Table 7

Technical comparison.

\begin{tabular}{|c|c|c|}
\hline & Ethanol plant & Power plants \\
\hline Annual production & $37,000,0001$ & $677 \mathrm{GWh}$ \\
\hline Electricity required per year & $13.38 \mathrm{GWh} /$ year $^{\mathrm{a}}$ & oGWh/year \\
\hline $\begin{array}{l}\text { Heat demanded by the } \\
\text { internal process }\end{array}$ & $68.2 \mathrm{GWh} /$ year & o GWh/year \\
\hline Annual energy equivalent save & $\begin{array}{l}18.43 \text { millions } \\
\text { of Ktep }\end{array}$ & $\begin{array}{l}233.74 \text { millions } \\
\text { of Ktep }\end{array}$ \\
\hline
\end{tabular}

Source: Authors.

a These data had been obtained extrapolating the mass and energy balances of producing ethanol form banana. Both processes are similar and do not affect the rigour of the study.

$\mathrm{b}$ The use of ethanol reduces the consumption of this quantity of gasoline 95 (in energy terms).

c Equivalent energy savings in a power station.

It should be noted that 37 million litres of ethanol in the market reduce the consumption of gasoline 95 by an amount of 13.74 million litres. Ethanol is not charged with the hydrocarbons special tax. Hence, an amount of 10.94 million euros per year is not collected by the authorities. The Net Present Value of this tax reduction is 125.808 million euros and should be taken into account.

\subsection{Mass and energy balances}

Table 9 shows the mass and energy balances for the ethanol plant.

Table 10 shows the mass and energy balances for power plants.

Table 8

Economic comparison.

\begin{tabular}{lll}
\hline & Ethanol plant & Power plants \\
\hline NPV & 35.79 million $€$ & 169 million $€$ \\
RI & $89 \%$ & $85 \%$ \\
IRR & $11 \%$ & $13 \%$ \\
Payback period & 10 years & 10 years \\
\hline
\end{tabular}

Source: Authors.

Table 9

Annual mass and energy balances for the ethanol plant.

\begin{tabular}{llll}
\hline Input & \multicolumn{3}{l}{ Output } \\
Mass balance & & & \\
$\begin{array}{l}\text { Citric waste } \\
\mathrm{NaOH}, \mathrm{H}_{2} \mathrm{SO}_{4} \text {, enzymes, }\end{array} \quad 462,500 \mathrm{Tm}$ & Ethanol & $29,378 \mathrm{Tm}$ \\
$\quad$ water, anti-foam, $\mathrm{K}_{2} \mathrm{HPO}_{4}$ & & $\mathrm{CO}_{2}$ & $29,075 \mathrm{Tm}$ \\
Energy balance & & Biomass & $406,739 \mathrm{Tm}$ \\
Electric energy & $13.37 \mathrm{GWh}$ & Electric energy & $0 \mathrm{GWh}$ \\
Heat energy & $19.00 \mathrm{GWh}$ & Heat energy & $0 \mathrm{GWh}$ \\
& & Ethanol & $219 \mathrm{GWh}$ \\
\hline
\end{tabular}

Source: Authors.

Table 10

Mass and energy balances for power plants.

\begin{tabular}{llll}
\hline Input & \multicolumn{3}{l}{ Output } \\
\hline $\begin{array}{l}\text { Mass balance } \\
\text { Citric waste }\end{array}$ & $462,500 \mathrm{Tm}$ & $\mathrm{CO}_{2}$ & $752,950 \mathrm{Tm}$ \\
$\mathrm{O}_{2}$ & $569,800 \mathrm{Tm}$ & $\mathrm{H}_{2} \mathrm{O}$ & $258,065 \mathrm{Tm}$ \\
& & $\mathrm{N}_{2} \mathrm{O}$ & $21,275 \mathrm{Tm}$ \\
Energy balance & & & \\
Electric energy & $0 \mathrm{GWh}$ & Electric energy & $667 \mathrm{GWh}$ \\
Heat energy & $2148 \mathrm{GWh}$ & Heat energy & $1481 \mathrm{GWh}$ \\
\hline
\end{tabular}

Source: Authors. 
Table 11

$\mathrm{CO}_{2}$ balance for the ethanol plant. Data in Tm per year.

\begin{tabular}{|c|c|c|}
\hline & \multicolumn{2}{|l|}{ Scenarios } \\
\hline & Optimistic & Pessimistic \\
\hline \multicolumn{3}{|l|}{$\mathrm{CO}_{2}$ emissions } \\
\hline $\begin{array}{l}\mathrm{CO}_{2} \text { emissions for the citric waste } \\
\text { transportation }\end{array}$ & \multicolumn{2}{|c|}{2280} \\
\hline \multicolumn{3}{|l|}{$\begin{array}{l}\mathrm{CO}_{2} \text { emissions in the ethanol } \\
\text { production process }\end{array}$} \\
\hline \multicolumn{3}{|l|}{ Required heat $\mathrm{CO}_{2}$ emissions } \\
\hline Electric generation & & 65,292 \\
\hline Fuel oil generation & 5118 & \\
\hline Required electric energy $\mathrm{CO}_{2}$ emissions & \multicolumn{2}{|c|}{29,684} \\
\hline Ethanol combustion $\mathrm{CO}_{2}$ emissions & \multicolumn{2}{|c|}{56,112} \\
\hline Total $\mathrm{CO}_{2}$ emissions & 93,194 & 153,368 \\
\hline \multicolumn{3}{|l|}{$\mathrm{CO}_{2}$ emissions savings } \\
\hline Gasoline 95 not burned & \multicolumn{2}{|c|}{57,590} \\
\hline Oil transportation to refinery no done & \multicolumn{2}{|c|}{846} \\
\hline Total $\mathrm{CO}_{2}$ emissions savings & \multicolumn{2}{|c|}{58,454} \\
\hline $\mathrm{CO}_{2}$ Balance for the ethanol plant & 34,740 & 94,914 \\
\hline $\begin{array}{l}\mathrm{CO}_{2} \text { emissions increase (\%) versus } \\
\text { the use of gasoline } 95\end{array}$ & $62 \%$ & $166 \%$ \\
\hline
\end{tabular}

Source: Authors.

\section{6. $\mathrm{CO}_{2}$ balance}

The following considerations have been taken into account when calculating $\mathrm{CO}_{2}$ balances for both solutions:

- $\mathrm{CO}_{2}$ balance for citric waste starts at source, where raw material is produced.

- Savings of gasoline 95 and gas-oil in each case will be included.

- Two scenarios are established: an optimistic and a pessimistic one. These are a function of the technical solutions adopted in each case.

Table 11 shows the balance of $\mathrm{CO}_{2}$ for an ethanol processing plant. The pessimistic case considers that the heat required to process the raw material is generated using electric energy. The optimistic case considers that this heat is generated burning fuel

It must be noted that the use of ethanol as a substitute for gasoline 95 not only diminishes $\mathrm{CO}_{2}$ emissions but are increased by an amount between 62 and $166 \%$.

Table 12 shows the $\mathrm{CO}_{2}$ balance of power stations. Two scenarios are shown: the optimistic case considers that the electricity produced by the power plant is to replace the energy generated only by fuel oil power plants and the pessimistic one considers that the electricity generated in these two power plants
Table 12

$\mathrm{CO}_{2}$ balance for the power plants. Data in metric tons per year.

\begin{tabular}{|c|c|c|}
\hline & \multicolumn{2}{|l|}{ Scenarios } \\
\hline & Optimistic & Pessimistic \\
\hline \multicolumn{3}{|l|}{$\mathrm{CO}_{2}$ emissions } \\
\hline $\mathrm{CO}_{2}$ emissions from waste transportation & \multicolumn{2}{|c|}{1330} \\
\hline $\begin{array}{l}\mathrm{CO}_{2} \text { emissions due to citric waste } \\
\text { combustion process }\end{array}$ & \multicolumn{2}{|c|}{755,342} \\
\hline Total $\mathrm{CO}_{2}$ emissions & \multicolumn{2}{|c|}{756,654} \\
\hline \multicolumn{3}{|l|}{$\mathrm{CO}_{2}$ emissions savings } \\
\hline Optimistic & & 337,706 \\
\hline Pessimistic & 589,907 & \\
\hline Oil transportation to power plants not done & 20,647 & 11,820 \\
\hline Total $\mathrm{CO}_{2}$ emissions savings & 610,554 & 349,526 \\
\hline $\mathrm{CO}_{2}$ balance for the power plants & 146,101 & 407,128 \\
\hline $\mathrm{CO}_{2}$ emissions increase & $19 \%$ & $54 \%$ \\
\hline
\end{tabular}

Source: Authors.

is not to be generated by the mix of power plants from the Iberian Peninsula.

\subsection{Comparison results}

A full review of the objectives of the 2003/30/EC directive in order to know how both solutions accomplish them is to be done.

\subsection{First objective: "Meeting climate change commitments"}

- Ethanol plant: This solution does not comply with this objective because ethanol $\mathrm{CO}_{2}$ emissions are higher than the equivalent gasoline 95 emissions. When both fuels burn, ethanol generates less $\mathrm{CO}_{2}$ than gasoline 95 , but to produce ethanol requires energy and this energy emits $\mathrm{CO}_{2}$ when it is produced. Besides, the $\mathrm{CO}_{2}$ removed from the atmosphere by the plants used to produce ethanol is not considered because the raw material is a waste material. By producing ethanol using this waste no more $\mathrm{CO}_{2}$ is captured from the atmosphere.

- Power plants: This solution does not comply with this objective because these power plants generate more $\mathrm{CO}_{2}$ than the equivalent fuel oil power plants.

\subsection{Second objective: "Environmentally friendly security of supply"}

- Ethanol plant: This solution complies with this objective because this plant assures the production of 37 million litres of ethanol per year. This ethanol avoids the imports of oil to obtain 13.74 million litres of gasoline 95 (18.44 million Ktep).

Table 13

Some other indicators to compare both solutions.

\begin{tabular}{|c|c|c|}
\hline & Ethanol plant & Power plants \\
\hline NPV without taking into account the income of the fuel tax & 35.79 million $€$ & 169 million $€$ \\
\hline Tax income reduction & 125.808 million $€$ & \\
\hline Imported oil annual equivalent savings & 18.44 million Ktep & 233.75 million Ktep \\
\hline $\mathrm{CO}_{2}$ emissions ( $\mathrm{Tm}$ per year) & Between 35,604 and 95,778 & Between 166,747 and 418,948 \\
\hline $\begin{array}{l}\text { Increase of } \mathrm{CO}_{2} \text { emissions in comparison with the emissions } \\
\text { of the products that citric waste substitutes }\end{array}$ & Between $61 \%$ and $166 \%$ & Between $22 \%$ and $55 \%$ \\
\hline Citric waste energy (P.C.I.) & \multicolumn{2}{|c|}{$2148 \mathrm{GWh}$} \\
\hline Energy efficiency (measure on raw material energy) (P.C.I.) & $8.68 \%$ & $31.5 \%$ \\
\hline External products required for the solution (per year) & $\begin{array}{l}185 \mathrm{Tm} \mathrm{H}_{2} \mathrm{SO}_{4,}, 42 \mathrm{Tm} \mathrm{NaOH}, 268 \mathrm{Tm} \mathrm{K}_{2} \mathrm{HSO}_{4} \text {, } \\
\text { 4.6 Tm enzymes, } 55.5 \mathrm{Tm} \text { anti-foam }\end{array}$ & $569,800 \mathrm{Tm} \mathrm{O}_{2}$ from the air \\
\hline Sub products generated per year & $\begin{array}{l}29,075 \mathrm{Tm} \mathrm{CO} \mathrm{CO}_{2} \text { and } 406.739 \mathrm{Tm} \text { biomass } \\
\text { with a high percentage of } \mathrm{C}_{2}{ }^{\mathrm{a}}\end{array}$ & $\begin{array}{l}258,075 \mathrm{Tm} \mathrm{H}_{2} \mathrm{O} 752,950 \mathrm{Tm} \\
\mathrm{CO}_{2} 21,275 \mathrm{Tm} \mathrm{NO}_{2}\end{array}$ \\
\hline
\end{tabular}

Source: Authors.

${ }^{a}$ It is assumed that this biomass is not to be burned. If not, this biomass would produce a large quantity of $\mathrm{CO}_{2}$ that should be considered in the balance. This biomass waste has a high percentage of carbon. 
- Power plants: This solution complies with this objective because power plants generate enough energy not to import oil to obtain 215.64 million litres of fuel oil (233.75 million Ktep).

\subsection{Third objective: "Promoting renewable energy sources"}

- Ethanol plant: This solution complies with this objective, but an external energy input of electricity and heat is required to process the citric waste. Energy balance shows that the internal ethanol energy is bigger than the required energy for processing the citric waste and for transporting the citric waste from the origin to the plant. The energy required for the harvesting of citric fruits has not been taken into account: energy used in obtaining fertilizers, fuel spent in preparing the land for cultivation, etc.

- Power plants: This solution complies with this objective because no external energy input is required.

In order to compare properly both proposals, some other indicators are needed. These indicators are shown in Table 13.

In addition to this, a variation on the thermal plant may be considered: seawater desalination using the MED system. Reducing the electricity production by $10 \%$, more than $1500 \mathrm{~m}^{3}$ per hour of seawater may be desalinated. The MED desalinate alternative has the advantage over other systems (as reverse osmosis desalination, for instance) that the cost is low because MED system takes waste heat from the power plant. Nowadays there are some desalination plants based on reverse osmosis technology under construction in the area and an additional comparison should be made taking into account $\mathrm{CO}_{2}$ emissions and energy savings of power plants with MED technology to replace reverse osmosis plants.

\section{Conclusions}

Knowing the current situation of the prices for raw materials, forcing European countries to produce and consume biofuel is not profitable either for the European countries or for individual users. This is because, from an economic point of view, it is very difficult for biofuels to compete with mineral fuels. Mineral fuels are extracted from geological formations, processed and delivered to consumers while biofuels require the processing of the raw material which is a complex and expensive elaboration in terms of energy and economic cost.

In order to compete with gasoline 95 the price for ethanol should be $0.40 € / 1$ excluding taxes. If the price of ethanol remains stable, E85 will start to compete with gasoline 95 when it reaches a price of $2.2 € / 1$.

In relation to $\mathrm{CO}_{2}$ emissions, biofuel generates less gas than gasoline 95 when it burns. But it is necessary to take into account the $\mathrm{CO}_{2}$ emissions generated by the energy (electricity and heat) demanded by the process to obtain the biofuel. The process to obtain gasoline 95 generates much less $\mathrm{CO}_{2}$.

Raw materials for biofuels have absorbed $\mathrm{CO}_{2}$ before arriving at the processing plant but, in the case of citrus waste, this absorbed $\mathrm{CO}_{2}$ is not taken into account because the citrus has not been cultivated in order to produce ethanol but to produce food (fruits, juice, etc.). To process the citric waste will not increase the amount of $\mathrm{CO}_{2}$ absorbed by the environment.
The objective of this research is to show that the obligation marked by the EU directive is not consistent with its objectives because, at least, one of them is not accomplished: $\mathrm{CO}_{2}$ emissions.

The authors of this study suggest several ways to achieve the objectives of the EU directive without its obligation to implement it. The following alternatives are proposed:

- To reduce the maximum speed on highways. It is unpopular but it is very effective. It has an undesired collateral effect: the income from taxes would be reduced.

- To increase fuel prices by raising the special taxes on gasoline and diesel fuels. This will lead users to lower the speed on the roads and will encourage them to use public transportation. It would be an unpopular measure and could lead to higher inflation and could affect economic development in a negative way.

- To encourage the use of existing technologies in the market to reduce fuel consumption. There are hybrid cars that achieve significant reductions in fuel consumption compared to traditional cars. This technology is expensive and, as in the rest of the proposals, may cause a decline in tax revenues.

Finally, the objectives of the legislation must not be achieved only through action on the transportation. There are other areas where it is possible to achieve the objectives such as electricity market. In Spain, as it has been noted previously, for each $\mathrm{kWh}$ of electricity generated in power plants, an average $400 \mathrm{~g}$ of $\mathrm{CO}_{2}$ is generated. In France this value is only $90 \mathrm{~g}$. This is because French system relies mainly on nuclear power plants. In Spain and in Europe there is raw material for nuclear power plants and the technology and facilities for processing this material are well known. Hence, the three objectives set out in the Directive are achieved with an advantage: it is economically profitable. This solution has other drawbacks as the generation of radioactive waste and the lack of popularity of this energy source.

\section{References}

[1] 2003/30/EC Directive of the European Parliament and the Council-8th may 2003. On the promotion of the use of biofuels or other renewable fuels for transport.

[2] Rodriguez Sandra I, Roman Matthew S, Sturhahn Samantha C, Terry Elizabeth H. Sustainability assessment and reporting for the University of Michigan's Ann Arbor Campus Report No. CSSO2-04; April 2002.

[3] Blackburn WR. The sustainability handbook. London: Earthscan; 2007.

[4] Daly H. Beyond growth: the economics of sustainable development. Boston: Beacon Press; 1996.

[5] Bartlett A. Reflections on sustainability, population growth, and the environment-revisited revised version (January 1998) paper first published in Population \& Environment 1998;16(1):5-35.

[6] UN Energy. Sustainable bioenergy: a framework for decision makers; April 2007.

[7] Niven RK. Ethanol in gasoline: environmental impacts and sustainability review article. Renewable and Sustainable Energy Reviews 2005;9(6):53555. doi: 10.1016/j.rser.2004.06.003. ISSN 1364-0321.

[8] Pimentel D. Ethanol fuels: energy balance, economics, and environmental impacts are negative. Natural Resources Research 2003;12(June (2)).

[9] Cortez L, Griffin M, Scaramucci J, Scandiffio M, Braunbeck O. Considerations on the worldwide use of bioethanol as a contribution for sustainability. Management of Environmental Quality 2003;14(4):508-19.

[10] Red Eléctrica de España. El Sistema Eléctrico Español; 2007.

[11] eleconomista.es. Investigan producir bioetanol con residuos cítricos para motores flexibles; April 2007 [accessed 15 September 2008].

[12] fundacioncac.es. Bioetanol: hacia un combustible verde; June-July 2007. 